\title{
Empirical Testing of Dynamic Capital Structure Choice: Case of Russian Companies
}

\author{
Шахина Н.А. ${ }^{10}$, Кокорева М.C. ${ }^{11}$
}

The article presents the results of empirically testing the predictions of the dynamic trade-off theory on the data of 56 Russian medium-sized companies. We use the data from 2004 to 2008 and show that the management behavior follows the principles of the dynamic trade-off concept. According to our analysis, the optimal interval for the company leverage becomes narrower as the profitability, size, growth opportunities and tangibility of a firm increase. Statistically significant difference between the lower and upper bounds of the interval confirms that the management adjusts the debt level targeting the optimal interval but not a specific optimal level.

\section{Introduction}

There exists a vast volume of research on capital structure; however, there is no conclusive evidence in favour of one particular theory that would explain the management decisions with regards to leverage. This area draws a lot of attention as the capital structure decision is critical for the value of a firm. Despite the apparent relevance, there is still very little research on capital structure in the emerging markets; most papers tend to focus on mature economies.

The Russian market is no exception. The existing papers about the Russian market focus on testing the basic theories, pecking order and static trade-off theories [Razmochaev, Berezinets and Volkov, 2010] and comparing the determinants of capital structure across the emerging markets [Ivashkovskaya, Solntseva, 2009]. However, the most recent papers in the developed markets examine the dynamic models which are more flexible in explaining the capital structure. Our paper contributes to the existing literature by presenting the results of testing the predictions of the dynamic trade-off theory based on a sample of 56 Russian midcap companies.

This article proceeds as follows. First, we present a review of existing literature on the dynamic version of trade-off capital structure theory. Then we proceed to describe the sample and key variables of the analysis. The third section introduces the methodological framework of the research. Finally, we present the results of the estimation and provide the interpretation. The last section concludes the article.

\section{Dynamic trade-off theory: overview and existing research}

The inquiry into the firms' capital structure started with Modigliani and Miller [Modigliani and Miller, 1958], who showed that under a given set of assumptions the capital structure does not affect the value of the firm. That paper sparked a vast amount of empirical and theoretical research and can be thought of as the foundation of modern capital structure theories. The first capital structure theory, the static trade-off theory, relaxes the assumption of the absence of corporate taxes. The result is that under the static trade-off theory a firm can achieve an optimal debt level that would balance the benefits of tax shield (tax benefits of debt, since interest is tax-deductible) and the potential costs of financial distress, which increase with higher debt levels. However, the static trade-off theory fails to explain several empirical regularities, such as negative correlation between return on assets (ROA) and leverage, as well as leverage and market-to-book ratio. Furthermore, the substantial deviations from the optimal leverage level and significantly different leverage levels for seemingly identical firms could not be reconciled with the theory. These

\footnotetext{
${ }_{10}^{10}$ Выпускница МИЭФ, студентка магистратуры Cass Business School (City University London)

11 Преподаватель кафедры экономики и финансов фирмы НИУ-ВШЭ, исследователь лаборатории корпоративных финансов
} 
inconsistencies led to the development of an alternative theory, the pecking-order theory of capital structure.

According to the pecking order theory, in the conditions of information asymmetry, a firm prefers to use internal funding (retained earnings and other reserves); when the internal source is exhausted, the firm would use the riskless debt, then the risky forms of debt. Equity will be considered as the last resort.

However, the pecking order theory is not the only way to overcome the drawbacks of the static trade-off theory. Some of the puzzles could be resolved by introducing adjustment (recapitalization) costs, which exist due to agency problems and information asymmetry. What emerged was the dynamic trade-off theory that examines the decisions in a multi-period setting and accounts for expectations and recapitalization costs. In particular, the transaction costs associated with issuing debt and equity prevent the firm from constantly adjusting its capital structure to the optimal level. As a result, the company targets an optimal leverage interval rather than a particular level and adjusts the capital structure only when the leverage breaks out of the interval [Fischer et al., 1989].

The dynamic version of the trade-off theory can explain the negative correlation between profitability and leverage. Strebulaev argues that for a firm that rarely alters its capital structure, increased profitability reduces the leverage through higher expected profits and thus total firm value [Strebulaev, 2007]. Similarly, a decrease in profitability would increase leverage. Since most companies prefer not to recapitalize too often, there would be a negative relationship between profitability and leverage. The key insight of dynamic theory in general is that the capital structure decisions heavily depend on the expectations and the costs of adjustment.

The existing papers on the dynamic trade-off theory focus on examining the determinants of the width of the optimal interval for the capital structure [Fischer et al., 1989; Dudley, 2007], determinants of the speed of adjustment in case the debt-to-equity ratio is not within the optimal range [Dang, Kim and Shin, 2009; Leary and Roberts, 2005] and the symmetry of the firm's policy if the $\mathrm{D} / \mathrm{E}$ is above or below the optimal interval boundaries [Dudley, 2007]. Furthermore, several papers empirically test the predictions of the dynamic trade-off theory [Fischer et al., 1989; Strebulaev, 2007; Dang, Kim and Shin, 2009] and examine the adjustment costs [Dang, Kim and Shin, 2009].

Some papers introduce a model for estimating the thresholds of the optimal interval. For instance, Fischer models the relation between the value of a firm and various parameters, including the boundaries of the optimal leverage level [Fischer et al., 1989]. However, the drawback of the approach is that Fischer offers an explicit value function, which requires numerous assumptions and hence is not robust. Dudley offers an approach that does not require such a function [Dudley, 2007].

There are only a handful of papers that analyse the post-adjustment leverage. Fischer suggests that the management tries to adjust the leverage to the optimal level as soon as it leaves the optimal interval, irrespective of which boundary was crossed [Fischer et al., 1989]. Mauer and Triantis, on the other hand, argue that the post-adjustment leverage level depends on which boundary was crossed [Mauer and Triantis, 1994].

Recent papers on adjustment costs agree that management decisions with regards to capital structure decisions depend on the type of costs the firm faces. Dang, Kim and Shin show that the corrections are asymmetrical hence the adjustment costs are not fixed and depend on the direction of the adjustment [Dang, Kim and Shin, 2009].

Most of the papers mentioned above use the data on developed markets, while emerging markets still lack thorough investigation. Emerging markets research generally focuses on analysing leverage determinants and testing the static trade-off and pecking order theories. Singh and Kumar examine Indian companies [Singh and Kumar, 2008], Mazur looks at Polish firms [Mazur, 2007], Ivashkovskaya and Solntseva analyse the capital structure across BRIC countries [Ivashkovskaya and Solntseva, 2008]. Russian companies are examined in Razmochaev, Berezinets and Volkov [Razmochaev, Berezinets and Volkov, 2010] and Ivanov [Ivanov, 2010]. The results of the research differ substantially, therefore a straightaway generalization is impossible. Furthermore, the inquiries 
into the empirical implications of the dynamic theories are even more rare [Clark et al., 2009].

Therefore, this paper aims to contribute to the existing body of literature by empirically testing the predictions of the dynamic trade-off theory in the Russian market. We look at the determinants of the capital structure for the Russian companies and analyse them in relation to the dynamic trade-off theory. Additionally, we examine the determinants of the optimal leverage interval.

\section{Sample description}

This section describes the formation of the sample to be used for the empirical tests in this paper. The basis for the sample is the RTS2 index. We add the companies that are not included in RTS2 but have similar annual sales (USD 0.7-3bn). Financial services and real estate firms were excluded from the sample due to their specific capital structure and financing policy. We also exclude firms with no debt financing ${ }^{12}$. The firms in the sample have financial statements for 20042008 prepared under IFRS. The data is provided by Bloomberg database; any missing entries were completed on the basis of the company reports. All the financial data were converted into USD using the exchange rates provided by OANDA [www.oanda.com]. The balance sheet figures were converted using end-of-year exchange rates, while the income statements and cash flow statements were converted using yearly average exchange rates. As a result, the sample produced is a balanced panel that contains data for 56 companies for $2004-2008$, a total of 280 observations.

\section{Variables description}

This paper uses balance sheet figures to calculate the leverage as the ratio of total debt (both long term and short term borrowings) to total assets. We do not examine the leverage based on market values as that would severely decrease the number of observations available. Moreover, midcap companies are thinly traded, which means the market values may not reliably reflect the capital structure at a given point of time.

To analyse the change in the capital structure, we use the pre- and post-issue leverage calculated as follows:

$$
\begin{aligned}
& \text { pre issue leverage }=\frac{\text { pre issue debt }}{\text { pre tssue assets }}(1) \\
& \text { post issue leverage }=\frac{\text { post issue debt }}{\text { preissue assets + net debt issue }}
\end{aligned}
$$

net debt issue $=$ post issue debt - pre issue debt (3)

Our dependent variable, $\mathrm{y}_{\mathrm{i}}$, is a discrete variable that depends on the change in leverage. It takes the value of 1 if the difference between pre- and post-issue leverage exceeds the threshold value of $\mathrm{q},-1$ if the difference is below -q. If the absolute value of the difference is lower than the threshold value, the dependent variable is 0. Following Dudley [Dudley, 2007], we use $2 \%$ as the threshold level.

Our list of dependent variables includes the determinants commonly used for testing the dynamic trade-off models. Profitability is calculated as return on assets (net income to total assets) [Dang, Kim and Shin, 2009]. According to the dynamic trade-off theory, more profitable companies closely adhere to the optimal capital structure because of higher tax shield benefits, hence optimal the interval is expected to be narrower.

The size of the company, calculated as natural logarithm of sales or total assets, is usually positively correlated with leverage, for large firms are more financially sound. On the other hand, recapitalization costs are relatively low for larger firms [Dang, Kim and Shin, 2009], therefore a narrower optimal interval should be expected.

\footnotetext{
${ }^{12}$ According to Dudley, the dynamic trade-off theory cannot explain the total absence of debt [Dudley, 2007], thus it is critical to exclude these firms from the analysis. Fischer demonstrates that it is always beneficial for a firm to have a positive level of debt [Fischer et al., 1989].
} 
The cost of financial distress is proxied by tangibility, calculated as fixed assets to total assets [Ivashkovskaya and Solntseva, 2008]. Fixed assets serve better as collateral and don't lose as much in value in conditions of financial distress [Frank and Goyal, 2007]; therefore a firm with high tangibility is expected to have higher debt level due to higher creditworthiness. At the same time, tangibility should be negatively correlated with the width of the optimal leverage interval [Fischer et al., 1989].

Another traditional variable in trade-off theory is the tax shield. The higher the effective tax rate (calculated as taxes paid to pretax earnings), the more beneficial high debt levels are, due to tax-deductibility of interest charges [Mazur, 2007]. According to the dynamic trade-off concept, the optimal interval width is smaller for a higher effective tax rate. Non-debt tax shield is used as well, calculated as depreciation expense to total assets. It is considered to be a substitute for the tax shield from debt, so the optimal debt level can be lower and the interval wider.

According to the trade-off theory, firms with high growth opportunities, calculated as capital expenditures to total assets, suffer more in cases of financial distress. Thus, firms with high growth opportunities are expected to have lower optimal leverage levels. In the dynamic framework it will imply a smaller optimal interval.

Finally, the riskiness can be defined as percentage change in operating earnings. Firms with more volatile earnings are not expected to recapitalize too often, as the costs of adjustment are higher [Mazur, 2007]. Hence the optimal interval should be wider [Fischer et al., 1989].

\section{The model for the boundaries of the optimal capital structure}

The methodology of our research is based on the model proposed by Dudley [Dudley, 2007]. The dynamic trade-off theory assumes that additional debt is issued when the leverage crosses the lower boundary of the optimal interval and debt is repurchased when the upper boundary is crossed. As a result, a new debt issue is expected if in the previous period $z_{i}$ was lower than $\mathrm{L}_{\mathbf{i}}$ and a repurchase is expected if $\mathrm{z}_{\mathrm{i}}>\overline{\mathrm{L}_{1}}$.

$$
\begin{aligned}
& \frac{z}{1-z}-\frac{\text { Dobt }}{\text { Equtty }} \\
& z=\frac{\text { Debt }}{\text { Assets }} \quad(5) \\
& y_{i}=\left\{\begin{array}{cc}
0, \quad \underline{L_{i}} \leq z_{i} \leq \overline{L_{i}} \\
-1, & z_{l}>\overline{L_{i}} \\
1, & z_{t}<\underline{L_{i}}
\end{array}\right.
\end{aligned}
$$

Then the functions $f_{1}$ and $f_{2}$ are introduced as

$f_{1}\left(x_{1 i}, \beta_{0}, \epsilon_{i}\right)=\frac{e^{\hat{x}_{1 i} \beta_{\mathrm{c}}-\varepsilon_{i}}}{1+e^{\hat{x}_{1 i} \beta_{0}+\varepsilon_{i}}}$

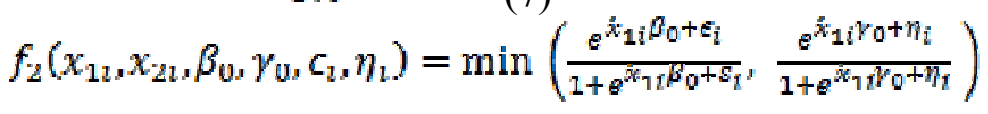

The upper $\left(\bar{L}_{i}\right)$ and the lower $\left(\frac{L_{i}}{-}\right)$ bounds are the functions of the following variables:

$\overline{L_{i}}=f_{1}\left(x_{1 i \dot{i}} \beta_{0}, \epsilon_{i}\right), \underline{L_{i}}=f_{2}\left(x_{1 i}, x_{2 i}, \beta_{0}, \gamma_{0}, \epsilon_{i}, \eta_{i}\right)$

where the vector $\left(\varepsilon_{\mathrm{i}}, \eta_{\mathrm{i}}\right)$ has a bivariate normal distribution. Moreover, $\varepsilon_{\mathrm{i}}$ and $\eta_{\mathrm{i}}$ are assumed independent to simplify the calculations, although the existence of correlation is more realistic. Therefore:

$$
\operatorname{Var}\left(\varepsilon_{\mathrm{i}}\right)=\sigma_{\varepsilon}^{2} \text { и } \operatorname{Var}\left(\eta_{\mathrm{i}}\right)=\sigma_{\eta}^{2}(10)
$$

Nevertheless, the correlation problem is not that critical as $f_{2}$ is expressed as a minimum of two exponential functions, which allows to take into account the correlation between the boundaries. 
By construction, the values of $L_{\mathbf{i}}$ and $\overline{L_{i}}$ lie between zero and one, and the lower bound is necessarily below the upper one. This is consistent with the possible range for leverage values (as expressed by total debt to total assets).

Thus the model allows the estimation of the boundaries that are unique for each firm and are dependent on the firm characteristics. To analyze the bounds, it is necessary to introduce the probability functions for each possible level of $y_{i}$ :

$$
\begin{aligned}
& I^{2}\left(y_{i}=1 \mid x_{1 i}, x_{2 i}, z_{i}\right) \\
& P\left(y_{i}=0 \mid x_{1 i}, x_{2 i}, z_{i}\right) \\
& P\left(y_{l}=-1 \mid x_{12}, x_{2 l}, z_{2}\right)
\end{aligned}
$$

Expectation of $\mathrm{y}$ is then determined as:

$$
\begin{aligned}
& E\left(y_{i}\right)=1 \cdot P\left(y_{i}=1 \mid x_{1 i}, x_{2 i}, z_{i}\right)+(-1) \cdot P\left(y_{i}=-1 \mid x_{1 i}, x_{2 i}, z_{i}\right)+0 \cdot P\left(y_{i}=0 \mid x_{1 i}, x_{2 i}, z_{i}\right) \\
& E\left(y_{i}\right)=P\left(y_{i}=1 \mid x_{1 i}, x_{2 i}, z_{i}\right)-P\left(y_{i}=-1 \mid x_{1 i}, x_{2 i}, z_{i}\right) \\
& \bar{S}_{i}=x_{1 i} \beta_{0}+\epsilon_{i} \\
& S_{i} \equiv x_{2 i} Y_{n}+\eta_{i}
\end{aligned}
$$

$$
\begin{gathered}
P\left(y_{t}=-1 \mid x_{1 t}, x_{2 t}, z_{t}\right)=P\left(z_{t}>\frac{e^{\bar{s}_{t}}}{1+e^{\bar{s}_{i}}}\right)=P\left(1-z_{t}<\frac{e^{\bar{s}_{t}}}{1+e^{\bar{s}_{i}}}\right)=P\left(\bar{S}_{t}<\log \left(\frac{z_{i}}{1-z_{i}}\right)\right. \\
=\Phi\left(\frac{\log \left(\frac{z_{t}}{1-z_{i}}\right)-x_{1 t} \beta_{0}}{\sigma_{\varepsilon}}\right)
\end{gathered}
$$

$$
\begin{aligned}
& P\left(y_{t}=1 \mid x_{1}, x_{2 t}, z_{t}\right)=P\left(z_{i}<\min \left[\frac{e^{\bar{S}_{t}}}{1+\bar{s}_{i}}, \frac{e^{S_{t}}}{1+e^{S_{i}}}\right]\right)=P\left(z_{t}<\frac{e^{\bar{s}_{t}}}{1+\bar{s}_{i}}\right) P\left(z_{t}<\frac{e^{S_{I}}}{1+e^{S_{i}}}\right)= \\
& {\left[1-\Phi\left(\frac{\log \left(\frac{z_{i}}{1-z_{i}}\right)-x_{1 i} \beta_{0}}{\sigma_{\varepsilon}}\right)\right]\left[1-\Phi\left(\frac{\log \left(\frac{z_{i}}{1-x_{i}}\right)-x_{2 i} \gamma_{0}}{\sigma_{\eta}}\right)\right]} \\
& \mathrm{P}\left(y_{1}=0 \mid x_{1 \mid}, x_{71}, z_{1}\right)=1-\mathrm{P}\left(y_{1}=1 \mid x_{11}, x_{7,}, z_{1}\right)-\mathrm{P}\left(y_{1}=-1 \mid x_{11}, x_{2 \mid}, z_{1}\right)(20)
\end{aligned}
$$

We use Non Linear Least Squares (NNLS) to estimate the above functions. Maximum likelihood method is also acceptable but is more complicated and gets minus infinity value in case of null probability. To use NNLS method the following function is used:

$$
\omega=\operatorname{argmin} \frac{1}{n} \sum_{i=1}^{n}\left(y_{i}-E_{\omega} y_{i}\right)
$$

where $\omega$ is a set of parameters

We use robust standard errors to address the heteroscedasticity problem.

In order to determine the impact of a particular variable on the probability of getting a given value of $y$, we take the derivative of the probability function with respect to that variable. To arrive at a numeric value of the derivative we use the mean values of the variables.

\section{Results of leverage optimal interval estimation}

At the first step we tested a model 1 that included all the described above independent variables (ROA, tangibility, growth, lnsales, non debt tax shield, tax shield, volatility (risk)). To avoid the possible multicollinearity problem the correlation matrix was built (table 9 of the appendix). Although the correlation between variables is not high, almost all variables of these models are insignificant at any reasonable significance level. We believe that the problem is with non debt tax shield and tangibility variables. Both of the variables are widely used in capital structure analysis and serve as proxies for different leverage determinants. Nevertheless the more 
tangible assets a firm has the more non debt tax shield should be. Thus, we decided to drop one of the variables from the analysis. We proceeded with different specifications the results for which could be observed in table 1 and tables 5-7 of the appendix.

Estimation of optimal frontiers by model 2

\begin{tabular}{llllccc}
\hline frontier & $\mathbf{y 2}$ & Coef. & $\begin{array}{c}\text { Std. } \\
\text { Err. }\end{array}$ & $\mathbf{t}$ & $\mathbf{P}>|\mathbf{t}|$ & $\begin{array}{c}\text { Expected } \\
\text { sign }\end{array}$ \\
\hline Lower & constant & 3.485199 & 1.890 & 1.844 & 0.065 & \\
& ROA & 0.0749005 & 0.036 & 2.104 & 0.035 & + \\
& Tang & -3.806326 & 1.017 & -3.741 & 0.000 & + \\
& lnsales & - & 0.244 & -1.856 & 0.063 & + \\
& & 0.4528367 & & & & \\
Upper & growth & 3.421201 & 2.586 & 1.323 & 0.186 & + \\
& constant & 20.4687 & 6.993 & 2.927 & 0.003 & \\
& ROA & - & 0.315 & 3.077 & 0.002 & - \\
& & 0.9684824 & & & & \\
& Tang & -16.6027 & 3.765 & -4.409 & 0.000 & - \\
& lnsales & -2.523278 & 0.791 & -3.192 & 0.001 & - \\
& growth & -43.9873 & 14.113 & -3.117 & 0.002 & - \\
\hline
\end{tabular}

Although the results of various models testing are quite robust we chose model 2 as a final one that provides us with the significant results that are robust and could be interpreted. We used the results of this model for the derivatives calculation.

Derivatives estimation for model 2

\begin{tabular}{ll|lll|ll}
\hline $\mathbf{d P}(\mathbf{y}=-\mathbf{1}) / \mathbf{d x}$ & & \multicolumn{2}{|l|}{$\mathbf{d P}(\mathbf{y}=\mathbf{0}) / \mathbf{d x}$} & $\begin{array}{l}\text { Expected } \\
\text { sign }\end{array}$ & $\mathbf{d P}(\mathbf{y}=\mathbf{1}) / \mathbf{d x}$ \\
\hline ROA & -0.256 & ROA & -0.151 & - & ROA & 0.105 \\
Tang & 4.385 & Tang & -2.418 & - & Tang & -1.968 \\
lnsales & 0.666 & lnsales & -0.376 & - & lnsales & -0.290 \\
growth & 11.619 & growth & -7.347 & - & growth & -4.272 \\
\hline
\end{tabular}

Table 2 presents the results of probability function derivatives with respect to the determinants. We have found that profitability (ROA) is significant and the optimal interval is becoming less with the increase of profitability. The negative value of derivative $\mathrm{P}(\mathrm{y}=0)$ with respect to ROA is inconsistent with the dynamic trade-off theory predictions.

Both tangibility coefficients are less than zero. This fact complicates the interpretation of possible tangibility influence so the derivatives calculation is necessary. The derivative $\mathrm{P}(\mathrm{y}=0)$ with respect to tangibility is negative which means that tangibility growth leads to the narrowing of leverage optimal interval. This result is also consistent with the dynamic concept that predicts positive relationship between costs of financial distress and the width of optimal interval, or, formally $d P(y=0) / d$ Tangibili ty $<0$

Negative lnsales coefficient for the upper limit agrees with the theory as the size effect makes it easier to recapitalize. The $\mathrm{P}(\mathrm{y}=0)$ derivative is less than zero which is also predictable [Fisher et al., 1989].

The signs of the coefficients for the upper and lower thresholds (note, however, that only the upper is significant) as well as the derivative sign coincide with the expectations. The costs of potential financial distress are higher for firms with good growth opportunities. Therefore the latter 
will try not to deviate far from the optimal level and decrease leverage when it reaches the upper threshold.

The next step is to check whether the coefficients obtained in model 2 with NNLS method are reasonable and ensure that the upper boundary is greater than the lower one. To test this we calculated probabilities $\mathrm{P}(\mathrm{y}=1), \mathrm{P}(\mathrm{y}=-1), \mathrm{P}(\mathrm{y}=0)$ for each observation (formulas $18,19,20)$.

Then all the observations were divided into three groups according to the event with the highest probability $(\mathrm{P}(\mathrm{y}=1), \mathrm{P}(\mathrm{y}=-1)$ or $\mathrm{P}(\mathrm{y}=0))$. For groups with $\mathrm{y}=-1$ and $\mathrm{y}=1$ average preadjustment leverage was calculated. The results are presented in table 3.

Average values for upper and lower thresholds for model 2 specification

Table 3

\begin{tabular}{ll}
\hline Upper & Lower \\
\hline 0.329 & 0.269 \\
\hline
\end{tabular}

We followed the Dudley methodology [Dudley,2007] and used Wilcoxon rank-sum test to test the significance of the observed difference in boundaries. The null hypothesis is that the boundaries coincide, while the alternative states that they are statistically different. The results of the test (presented in table 4) conducted in Stata show that Z-statistics equals 8.55 and its p-value is 0.00. Consequently the null hypotheses should be rejected at any reasonable level of significance. Thus, the thresholds of the optimal interval exist and do not coincide. Moreover, as the average debt ratios for $\mathrm{y}=-1$ group is higher than for $\mathrm{y}=1$ group, we could summarize that the model correctly predicts whether the observed leverage is below or above the optimal interval bounds.

Table 4

Test for the difference between the thresholds

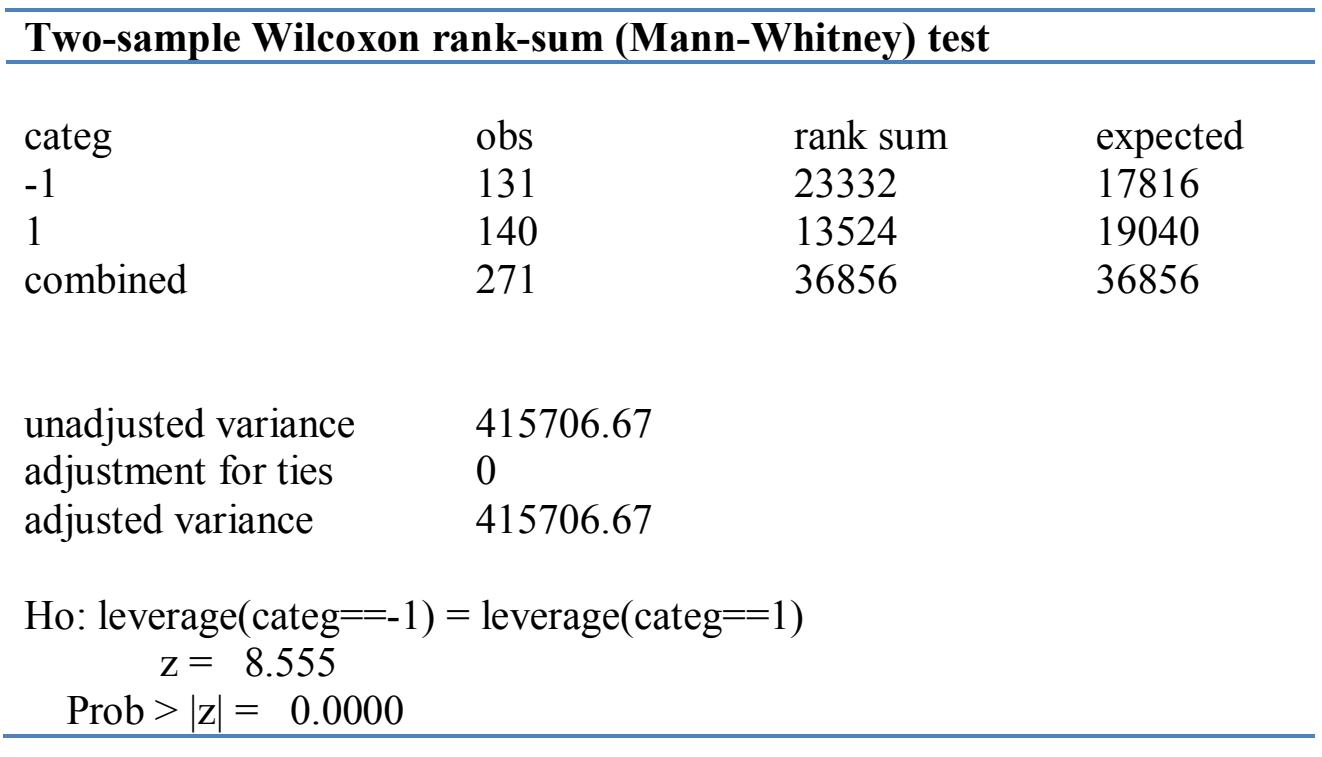

\section{Summary}

Dynamic trade-off theory predicts that managers take into account not only benefits and costs of the optimal debt-to-equity ratio while considering the firm's financing policy, but also recapitalization costs. Therefore, an optimal leverage interval should exist within which adjustment costs are higher than the benefits of optimal capital structure. Thus management should take recapitalization actions only in cases when the leverage of the firm crosses the thresholds of the optimal interval.

Our research conducted on a sample of Russian companies revealed that actions of Russian managers are compatible with the predictions of dynamic trade-off theory. The optimal leverage interval is decreasing with the growth of profitability, company size, tangibility and growth 
opportunities. The difference in upper and lower thresholds was found to be significant which means that managers target an optimal leverage interval but not a certain level.

The capital structure of Russian companies, in particular the speed of adjustment and the postadjustment leverage, requires further investigation. Moreover, other issues such as agency costs and behavioral factors provide ample opportunities for research.

\section{References}

1. Baker, M., \& Wurgler, J. (2002). Market Timing and Capital Structure. The Journal of Finance, 1-32.

2. Brennan, M. \& Schwartz, E. (1984). Valuation of Corporate Claims. Optimal Financial Policy and Firm Valuation. The Journal of Finance, 593-607.

3. Bradley, M. (1984). On the Existence of an Optimal Capital Structure: Theory and Evidence. The Journal of Finance, 857-878.

4. Clark B. \& Francis B. \& Hasan I. (2009) Do firms adjust toward target capital structures? Some international evidence. Working paper (http://ssrn.com/abstract=1286383).

5. Cotei, C., \& Farhat, J. (2009). The Trade-Off Theory and the Pecking Order Theory: Are they Mutually Exclusive? North American Journal of Finance and Banking Research, 1-16.

6. Dang, V., Kim, M., \& Shin, Y. (2009). Asymmetric Capital Structure Adjustments: New. Working Paper Series.

7. Delcoure, N. (2007). The determinants of capital structure in transitional economies. International Review of Economics and Finance, 400-415.

8. Dudley, E. (2007). Testing Models of Dynamic Trade Off Theory. Working Paper Series.

9. Fischer, E., Heinkel, R., \& Zechner, J. (1989). Dynamic Capital Structure Choice: Theory and Tests. The Journal of Finance, 19-40.

10. Flannery, M., \& Hankins, K. (2007). A Theory of Capital Structure Adjustment Speed. Working Paper Series.

11. Flannery, M., \& Rangan, K. (2006). Partial Adjustment toward Target Capital Structures. Journal of Financial Economics, 469-506.

12. Frank, M., \& Goyal, V. (2007). Trade-off and Pecking Order Theories of Debt. Working Paper Series.

13. Goldstein, R., Ju, N., \& Leland, H. (2001). An EBIT-Based Model of Dynamic. Journal of Business, 483-512.

14. Hennessy, C., \& Whited, T. (2005). Debt Dynamics. The Journal of Finance, 1129 - 1165.

15. Jensen, M., \& Meckling, W. (1976). Theory of the Firm: Managerial Behavior,. Journal of Financial Economics, 305-360.

16. Leary, M., \& Roberts, M. (2005). Do Firms Rebalance Their Capital Structures? The Journal of Finance, 2575 - 2619.

17. Mazur, K. (2007). The Determinants of Capital Structure Choice:. International Advances in Economic Research, 495-514.

18. Mauer, D., \& Triantis, A. (1994). Interactions of Corporate Financing and Investment Decisions: A Dynamic Framework.The Journal of Finance,. 1253-1277.

19. Modigliani F., Miller M.H. (1958) The Cost of Capital, Corporation Finance, and the Theory of Investment. American Economic Review, 48, pp. 261-297

20. Myers, S. (1984). The Capital Structure Puzzle. The Journal of Finance, 575-592.

21. Myers, S. (1993). Still Searching for Optimal. Journal of Applied Corporate Finance, 4-14.

22. Myers, S. (2001). Capital Structure. The Journal of Economic Perspectives, 81-102.

23. Myers, S., \& Majluf, N. (1984). Corporate Financing and Investment Decisions when Firms Have Informationthat Investors Do Not Have. Working Paper Series.

24. Singh, P., \& Kumar, B. (2008). Trade off Theory or Pecking Order Theory: What Explains the. Working Paper Series.

25. Strebulaev, I. (2007). Do Tests of Capital Structure Theory. The Journal of Finance, 1747 - 
1787.

26. Villamil, A. (2008). The Modigliani-Miller Theorem. The New Palgrave Dictionary of Economics.

27. Welch, I. (2002). Columbus' Egg: The Real Determinant of Capital Structure. NBER Working Paper No. 8782.

28. Иванов И. (2010) Детерминанты структуры капитала публичных российских компаний. Корпоративные финансы. № 1 (13). С. 5-38.

29. Ивашковская, И., \& Солнцева, М. (2008). Структура Капитала в Российских Компаниях Как Стратегическое Решение. Вестник Санкт-Петербургского Университета, 3-32.

30. Ивашковская, И., \& Солнцева, М. (2009). Детерминанты Стратегических Решений о Финансировании Крупных Компаний на Развивающихся Рынках Капитала: Пример России, Бразилии и Китая. Российский журнал менеджмента, 25-42.

31. Размочаев, А., Волков, Д., \& Березинец, И. (2010). Финансовые решения российских компаний: результаты эмпирического анализа. Вестник Санкт-Петербургского Университета.

32. Инвестиционная группа «Атон» - $\quad$ http://www.atonline.ru/study/manual/glava_8_akcii_vtorogo_eshelona

33. Информационный сайт по курсам валют -- http://www.oanda.com.

\section{Appendix}

Frontiers estimation results (Model 1 specification)

\begin{tabular}{llllll}
\hline frontier & $\mathbf{y 2}$ & Coef. & Std. Err. & $\mathbf{t}$ & $\mathbf{P}>|\mathbf{t}|$ \\
\hline Lower & constant & 10.11837 & 3.932002 & 2.57 & 0.011 \\
& ROA & 0.1033837 & 0.0384002 & 2.69 & 0.008 \\
& Tang & -0.9066789 & 1.444553 & -0.63 & 0.531 \\
& lnsales & -1.109575 & 0.4723951 & -2.35 & 0.02 \\
& growth & 8.05594 & 3.33543 & 2.42 & 0.017 \\
& ndts & -96.58357 & 24.2668 & -3.98 & 0 \\
Upper & constant & 47.10571 & 200.0976 & 0.24 & 0.814 \\
& ROA & 0.4234911 & 1.933149 & 0.22 & 0.827 \\
& Tang & -2.809022 & 56.83534 & -0.05 & 0.961 \\
& lnsales & -3.665187 & 13.13469 & -0.28 & 0.78 \\
& growth & -34.74036 & 171.3164 & -0.2 & 0.84 \\
& ndts & -115.1197 & 389.5723 & -0.3 & 0.768 \\
\hline
\end{tabular}

Frontiers estimation results (Model 3 specification)

\begin{tabular}{lllllll}
\multicolumn{6}{c}{ Frontiers estimation results (Model 3 specification) } \\
\hline frontier & $\mathbf{y 2}$ & Coef. & Std. Err. & $\mathbf{t}$ & $\mathbf{P}>|\mathbf{t}|$ & expected \\
\hline Lower & constant & -1.23577 & 1.944 & -0.636 & 1.475 & \\
& ROA & 0.092384 & 0.037 & 2.498 & 0.012 & + \\
& Tang & -4.31481 & 0.937 & -4.605 & 0.000 & + \\
& lnassets & 0.206347 & 0.263 & 0.786 & 1.568 & + \\
& growth & 4.263944 & 2.577 & 1.654 & 0.098 & + \\
Upper & constant & 20.31917 & 13.754 & 1.477 & 0.140 & \\
& ROA & 0.131689 & 0.188 & 0.700 & 0.484 & - \\
& Tang & -0.46708 & 7.747 & -0.060 & 0.952 & - \\
& lnsassets & -2.12754 & 1.554 & -1.369 & 0.171 & - \\
& growth & -7.45395 & 8.537 & -0.873 & 0.383 & - \\
\hline
\end{tabular}

Table 6 
Frontiers estimation results (Model 4 specification)

\begin{tabular}{lllllll}
\hline frontier & y2 & Coef. & Std. & $\mathbf{t}$ & $\mathbf{P}>|\mathbf{t}|$ & expected \\
\hline Lower & constant & 1.85285 & 1.790363 & 1.035 & 0.301 & \\
& ROA & 0.078863 & 0.03771 & 2.091 & 0.036 & + \\
& Tang & -2.69859 & 0.951565 & -2.836 & 0.005 & + \\
& lnassets & -0.26579 & 0.236582 & -1.123 & 0.261 & + \\
Upper & constant & 25.95482 & 15.17006 & 1.711 & 0.087 & \\
& ROA & 1.332488 & 0.896238 & 1.487 & 0.137 & - \\
& Tang & -59.2942 & 21.14243 & -2.805 & 0.005 & - \\
\hline
\end{tabular}

Table 7

Variables descriptive statistics

\begin{tabular}{llllll}
\hline Variable & Obs & Mean & Std. Dev. & Min & Max \\
\hline Insales & 270 & 6.741036 & 0.8507376 & 4.087286 & 8.955318 \\
roa & 270 & 6.235572 & 9.424943 & -28.3345 & 43.0314 \\
tangibility & 270 & 0.5543053 & 0.2141734 & 0.1425515 & 0.981295 \\
growth & 270 & 0.0915354 & 0.1281997 & -0.896036 & 0.584989 \\
bookleverage & 270 & 0.2731628 & 0.1675931 & 0.0012641 & 0.7575523 \\
debt/equity & 270 & 0.4682498 & 0.4283035 & 0.0012657 & 3.1246 \\
\hline
\end{tabular}

Table 9

Variable correlation matrix

\begin{tabular}{lllllllll}
\hline & Inassets & Insales & ROA & tangibility & growth & risk & $\begin{array}{l}\text { tax } \\
\text { shield }\end{array}$ & NDTS \\
\hline Inassets & 1 & & & & & & & \\
Insales & 0.737 & 1 & & & & & & \\
ROA & -0.2161 & -0.1546 & 1 & & & & & \\
tangibility & 0.2931 & 0.0664 & -0.0121 & 1 & & & & \\
growth & 0.1985 & 0.1632 & -0.1935 & 0.1764 & 1 & & \\
risk & -0.0736 & -0.0497 & -0.1951 & 0.0762 & -0.0231 & 1 & & \\
tax shield & -0.0619 & -0.0073 & 0.012 & -0.0095 & -0.0581 & 0.1558 & 1 & \\
NDTS & 0.0799 & 0.102 & -0.1963 & 0.4237 & 0.1952 & 0.0411 & 0.0154 & 1 \\
\hline
\end{tabular}

